\title{
「研究会に行こう！」では基礎・境界ソサイエティの各研究専門委員会の様子を御紹介しています. 前号に引き続き各研究会の研究専門委員長からの御挨拶をお届けします.
}

\section{口応用音響研究会 (EA)}

応用音響研究会 (EA) の委員長を務めさせて頂く三好正人 (金沢大学)です．まずは，このたびの東日本大震災による被害を受け られた皆様へ心からお見舞い申し上げます．被災地の一日も早い復興を祈念致しております．

さて，EAは「音」の収録・伝送·再生等に係る電気音響技術，及び音声，聴覚，音楽，騒音振動，建築，超音波等の隣接分野へ の様々な応用技術を研究発表\&討論の対象とし, マイクロホンやスピ一力等に係るハードウェア技術から音声音響信号処理に係る ソフトウェア技術に至る幅広い技術分野で活躍する専門家が集う，いわば，音響界の異文化交流の場を提供します．若手・ベテラ ンの隔てのないフランクで活発な意見交換を通して, 自らの研究に係る技術情報とともに, 隣接する他分野の知識を得る機会を提 供します

今年度は, 大阪 (5月; SIP, SP共催), 札幌 (6月; 日本音響学会音楽音響研究会 $(M A)$, 同聴覚研究会 $(H)$ 共催), 大阪 (7月 ; 日本音響学会建築音響研究会 $(A A)$ 共催), 仙台 (8月; H 共催), 長野 (10月), 熊本 (1 1月), 東京 (12月; EMM共催), 大阪 . 吹田 (1月； US共催), 東京 (3月)の計 10 回開催を予定しています。12月は, 新規発足したEMMとの共催にて, 異種メディ ア融合やコンテンツ処理等に係る「新しいコラボ」をスタートします，3月は，昨年度のリオン株式会社殿に続き，（株）日立製作 所中央研究所殿に会場と見学会を提供頂く予定です.

また,このたびの震災に鑑み開催を中止した研究会 (2011.3)に収録された論文については, 著者の御希望により, 10月, 11 月, 若しくは3月の研究会にて口頭発表頂く予定にしています，詳しくは各会会告を御覧下さい.

※応用音響研究会に係る最新情報は次のホームページに掲載しています。

http://www.soc.nii.ac.jp/asj/EA/index-j.html *

http://www.ieice.org/ken/program/index.php?tgid=EA\&lang=I

*東京地区電力事情のため現在は次の仮設サイトで運営しています。

http://www.hicc.cs.kumamoto-u.ac.jp/asj-ea/

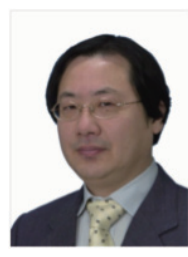

三好正人 (正員)

1983 同志社大大学院工学研究科博士課程前期了, 同年NTT入社，音響信号処理の理論，及び応用に関 わる基礎的研究開発に従事. 工博. 2009金沢大. 理工研究域·電子情報学類·教授. 2010 2011 応用音響研究専門委員会委員長. 2011 基礎·境界 ソサイエティ副会長.

\section{ロイメージ・メディア・クオリティ研究会 (IMQ)}

イメージメディアクウォリティ時限研究専門委員会は, 活発な活動が認められ, 2011 年4月1日から「時限」が取れてイメー ジ・メディア・クオリティ研究專門委員会 (以下IMQ) としてスタートしたばかりの研究会です.

高度情報通信技術が爆発的に普及する中, ディジタルカメラ, ディジタルムービー, ディスプレイ, プリント, 商業印刷, 放送, 通信, 蓄積, 合成といったディジタル化したイメージングメディアのシームレス化が一気に進んできました．これら像メディア全 てが同じ見えで, しかも高い画質が要求されるようになり，像メディア評価技術の重要性がますます高まっています，

本研究会は, 像メディア固有の評価技術研究とその応用の議論に加えて, 共通基盤研究との橋渡しや先達の研究の再確認を行う ことを目的として，多彩な研究者が集い，タイムリーな研究発表と研究交流，若手研究者の啓発を行っています．

以下に今後の活動予定を記します，初年度は，研究会活動の立ち上げと担当分野が広いので，研究者の裾野を広げて行き，人材 育成のための教科書編纂につなげていきたいと思っておりますので, 広い分野の技術者研究者に御参加頂して, 活発な御議論をお 願いしたいと思います。

研究会・ワークショップ等

（1）IMQA2011（国際ワークショップ: 平成23年 10月4日〜 5日，キャンパスプラザ京都）

（2） IMQ研究会(「画質とIMQ一般」: 平成23年 11 月25日, 富山大)

(3) $I M Q$ 研究会(「視覚亡 $I M Q$ 一般」: 平成24年3月2日, 鹿児島大) 
論文編集 (イメージメディアクウォリティ小特集)

（1）英文論文誌A小特集 (平成24年 8 月号予定)

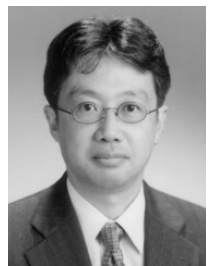

会津昌夫 (正員 : シニア会員)

昭 57 東工大大学院修士課程了, 平8東大大学院工 学系研究科電子工学専攻博士課程了. 平13キヤノン 入社, 画像処理, 色彩工学, 画質評価の研究開発・標 準化活動に従事。映像情報メディア学会理事, 日本照 明委員会理事を歴任し，平23よりイメージ・メディ ア・クオリティ研究専門委員会委員長. 博士 (工学).

\section{ロシステム数理と応用研究会 (MSS)}

本年度, MSS 研究会の委員長を務めます北陸先端大の平石邦彦ででざいます，本研究会について簡単ではありますが紹介させ て頂きます．

システム数理と応用研究專門委員会 (MSS: Mathematical Systems Science and Its Applications)は, コンカレントエ 学研究専門委員会 (CST) の名称変更という形で本年度より発足致しました. MSS研究会の対象とする研究領域は, 従来CSTが 主要なテーマとしていたコンカレントシステムに関する理論及び応用研究に加え, 形式手法などの数理的技術に基づいたシステム の設計・検証手法, サイバーフィジカルシステム, サービスサイエンス/ヒューマンファクターのための数理技術を含み, 更にオー プンシステムサイエンス、システムバイオロジーなどの新しい手法への展開を目指しています，もちろん，発足当初からこれら全 ての領域をカバーできるわけではありませんが, 大会のシンポジウム企画, 各研究会における招待講演などの機会を利用して, 徐々 に研究会の方向性を出していきたいと考えております．

MSS研究会では研究会を年4回開催する予定です．本年度は6月にシステムと信号処理サブソサイエティ4 研専合同の研究会 を沖縄で開催致しました. この研究会がMSS としての第 1 回の研究会になります. 今後は, 11 月に山口大学で回路とシステム 研究会 (CAS) 及び情報処理学会のアルゴリズム研究会と合同の研究会を, 2012 年 1 月に高知市でソフトウェアサイエンス研究 会 (SS) と合同研究会を, そして3月には東京·品川で単独の研究会を開催します. 大会における企画としては, 本年3月の総 合大会時に企画セッション「システム数理と応用 - CSTからMSSへ -」の開催を予定していましたが, 残念ながら東日本大震 災の影響で開催されなかったため,このときの講演者の方々には 1 月及び3月の研究会での御講演をお願いしています．9月の ソサイエティ大会ではシンボジウム「ワークフローとビジネスプロセス管理への数理的アプローチ」を予定しています. 来年3月 の総合大会時にも数理的アプローチによるバイオロジーの研究に関するシンポジウムを企画中です. 詳細は研究会ホームページ http://www.ieice.org/rmss/を御覧下さい.

システムを数理的技術により取り扱うことを共通点とした様々な研究領域を扱っていくつもりですので，この分野に御興味のあ る方は是非とも研究会に御参加下さるようお願い申し上げます

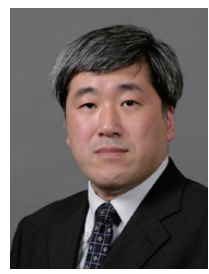

平石邦彦 (正員)

1983 東工大·工·制御卒, 1985 同大学院修士 課程了。1985 1993富士通秼及び侏富士通研究 所勤務. 1993 北陸先端大・情報科学研究科・助教 授. 2003 同教授. 工博. システムの形式的モデル 化，離散事象/ハイブリッドシステムの研究に従事. 平17年度本会論文賞受賞.

2011 年度から, 信頼性研究専門委員長を務めることになりました。微力ながら責務を果たしていきたいと存じます．よろし くお願し致します。

信頼性研究専門委員会 $(R)$ は長い歴史を持ち, 部品の信頼性からシステム, ソフトウェアの信頼性, そして信頼性に関する国 際標準化の動向まで, 信頼性工学に関する幅広い内容の研究発表と討論を行ってまいりました. 研究会を中心にソサイエティ大会, 総合大会を主な活動の場としております．

今年度の研究会開催予定は, 下記のとおりとなっております

$\begin{array}{ll}\text { 4月 } & \text { 機械振興会館 (OPE，CPM と共催) } \\ 5 \text { 月 } & \text { 高知市文化プラザ「かるぽーと」(高知市) } \\ \text { 6月 } & \text { 機械振興会館 } \\ \text { 7月 } & \text { 根室グランドホテル (根室市) }\end{array}$

